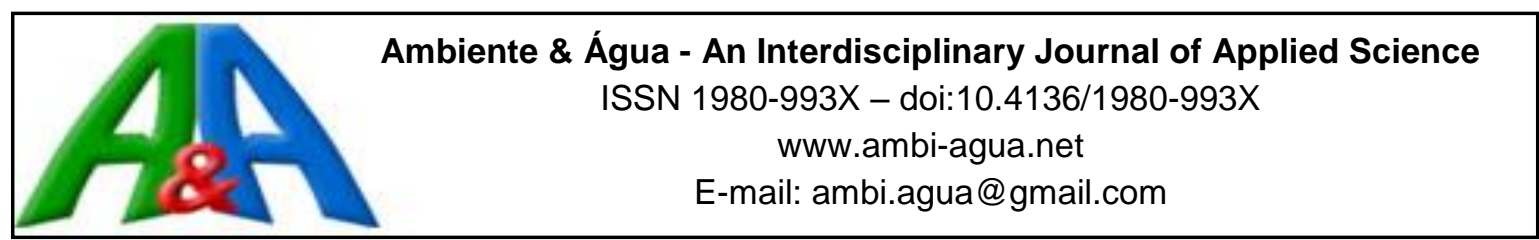

\title{
Trends in daily precipitation in highlands region of Santa Catarina, southern Brazil
}

\author{
ARTICLES doi:10.4136/ambi-agua.2149
}

Received: 14 Jun. 2017; Accepted: 26 Dec. 2017

\section{Eder Alexandre Schatz Sá ${ }^{1}$; Carolina Natel de Moura ${ }^{*}$; Victor Luís Padilha²; Claudia Guimarães Camargo Campos ${ }^{1}$}

\author{
${ }^{1}$ Universidade do Estado de Santa Catarina (UDESC), Lages, SC, Brasil \\ Departamento de Engenharia Ambiental e Sanitária. E-mail: ederalexsa@gmail.com, carolina.natel@gmail.com, \\ claudia.campos@udesc.br \\ ${ }^{2}$ Universidade Federal de Santa Catarina (UFSC), Florianópolis, SC, Brasil \\ Departamento de Engenharia Sanitária e Ambiental. E-mail: victor.engambiente@gmail.com \\ *Corresponding author
}

\begin{abstract}
This study evaluates the occurrence of trends in time series of precipitation in the highlands region of Santa Catarina, Southern Brazil. Daily precipitation data of three weather stations at Lages, São Joaquim and Campos Novos were used to evaluate rainfall trends. The trends were analyzed through the Seasonal Mann Kendall test, to include occurrence of maximum annual 1-day precipitation (RX1), maximum annual consecutive 2-day precipitation (RX2) and maximum annual consecutive 3-day precipitation (RX3) and evaluation of Rainfall Anomaly Index (RAI). Trends were identified in two of three weather stations investigated. Positive precipitation trends were found in the spring and winter for Lages, and in the spring and summer for São Joaquim. Also, there is a trend of increase in the RX1, RX2 and RX3 frequencies and an increase in positive anomalies in the last decade for these stations. There are no statistically significant trends in the precipitation of Campos Novos, which may be associated with the short series of available data for the analysis. The occurrence of El Niño phenomenon with moderate to strong intensity was usually associated with the occurrence of positive precipitation anomalies and the La Niña phenomenon was related to the occurrence of negative anomalies. However, the influence of La Niña in the periods of negative anomaly has been reduced since the beginning of the 21 st century.
\end{abstract}

Keywords: anomaly, rainfall, Mann-Kendall.

\section{Tendências na precipitação diária da região serrana de Santa Catarina, sul do Brasil}

\section{RESUMO}

Este estudo tem como objetivo avaliar a ocorrência de tendências em séries temporais de precipitação na região serrana de Santa Catarina, no sul do Brasil. As tendências foram analisadas através do teste Sazonal de Mann Kendall, frequências da precipitação máxima de 1 dia (RX1), precipitação máxima consecutiva de 2 dias (RX2) e precipitação máxima consecutiva de 3 dias (RX3) e avaliação do Índice de Anomalia de Chuva (RAI). Tendências foram identificadas em duas das três estações meteorológicas investigadas. As tendências 
positivas de precipitação foram encontradas na primavera e no inverno para Lages e na primavera e verão para São Joaquim. Além disso, há uma tendência de aumento das RX1, RX2 e RX3 e aumento de anomalias positivas na última década para essas estações. Não há tendências estatisticamente significativas na precipitação de Campos Novos, o que pode estar associado à curta série de dados disponíveis para a análise. A ocorrência do fenômeno de El Niño com intensidade moderada a forte geralmente foi associada à ocorrência de anomalias de precipitação positivas e o fenômeno de La Niña estava relacionado à ocorrência de anomalias negativas. Embora, observe-se que a influência de La Niña nos períodos de anomalia negativa foi reduzida desde o início do século XXI.

Palavras-chave: anomalia, chuva, Mann-Kendall.

\section{INTRODUCTION}

The analysis of precipitation time series in South America indicates the occurrence of a change in climatic behavior, with an increase in the magnitude and frequency of rainy days (Liebmann et al., 2004). This change in the rainfall patterns due to anthropogenic climate change, and decadal and multi-decadal climate variability call into question the stationary climate assumption, producing trends (IPCC, 2007) which are systematic and continuous changes in any parameter of a given sample, excluding periodic or quasi-periodic changes (Yevjevich, 1972).

A variation in spatial and temporal scale in the rainfall trend (Minuzzi and Caramori, 2011) has been observed, showing divergent trends in different locations of the world. Several studies of precipitation trend analysis were developed in Brazil using non-parametric statistical tests, which obtained results of absence of trend (Salviano et al., 2016; Noronha et al., 2016; Sanches et al., 2013), trend of increase (Uliana et al. 2015; Costa et al.; 2015; Pinheiro et al., 2013; Minuzzi and Caramori, 2011; Groppo et al., 2001; Back, 2001) or even decreasing trends and/or different trends of increase and decrease in the same work, according to the region under study (Raimundo et al, 2014; Blain, 2010; Lima et al., 2011), which justifies the study of precipitation trends on a regional scale.

It is expected that these changes affect ecosystems and hydrological cycles, with the intensification of extreme climatic events being one of the main global concerns, due to the possibility that these may affect the socioeconomic segments of energy, water supply and the occurrence of natural disasters in urban environments. The identification of the impacted sites by the effects of climate change makes it possible to estimate the damages to socioeconomic activities, aiding decision makers in the management of risks and adaptation to changes. This work therefore sought evidence of a possible increase or decrease in the rainfall amount, maximum 1-day precipitation, maximum consecutive 2-day precipitation and maximum consecutive 3-day occurrences and anomalies for the highlands region of Santa Catarina in Southern, Brasil, based on long-term daily precipitation time series.

\section{MATERIALS AND METHODS}

Daily precipitation data of three weather stations from INMET (National Meteorological Institute) were used to evaluate rainfall trends in the highlands region of State of Santa Catarina, Brazil (Fig. 1), Lages (OMM 83891), São Joaquim (OMM 83920) and Campos Novos (OMM 83887). These stations were selected because they have rainfall records for at least 29 years and are evenly spread throughout the study region. 


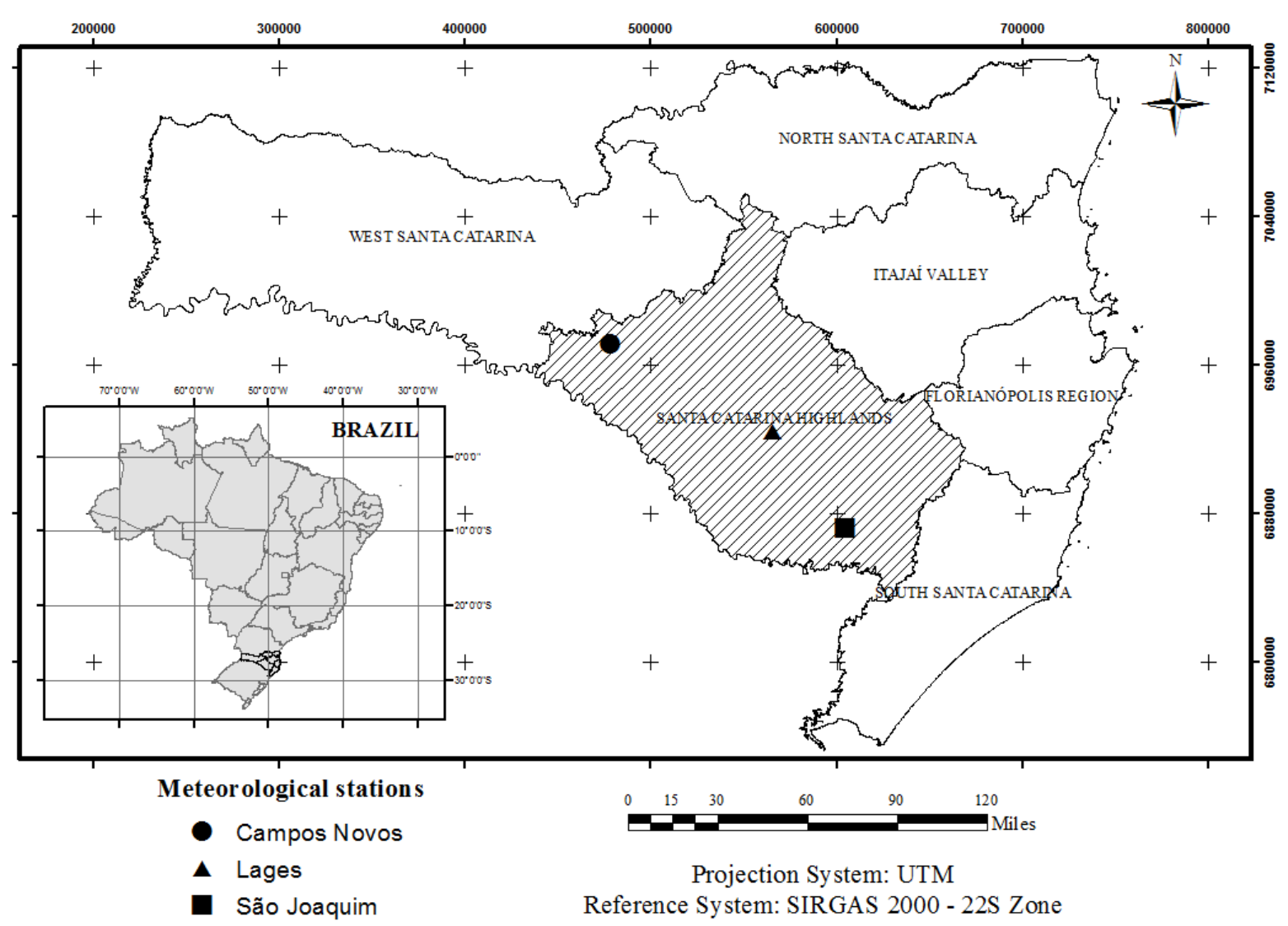

Figure 1. Study area and meteorological stations.

A data analysis was performed to identify the presence of missing data or inconsistencies in the time series. The years in which missing data exceeded $15 \%$ were excluded from the analysis in order to avoid bias in the study. The missing precipitation data were not estimated due to the great variability of precipitation, both spatially and temporally, which could lead to errors in the results. In this manner, a different period of analysis was chosen for the Campos Novos weather station (1987 to 2015), compared to Lages and São Joaquim (1961 to 2015), due to data availability.

Precipitation trends were analyzed using the Seasonal Mann-Kendall test (HIRSCH et al., 1982), analysis of occurrences of maximum 1-day precipitation (RX1), maximum consecutive 2-day precipitation (RX2) and maximum consecutive 3-day precipitation (RX3) and evaluation of Rainfall Anomaly Index (RAI).

The RX1, RX2 and RX3 rainfall indices analysed were adapted from the recommendations of Expert Team on Climate Change Detection and Indices (ETCCDI), developed by Climatic Variability and Predictability (CCI/CLIVAR), in which the maximum annual 1-day precipitation (RX1) was discretized in precipitations above $50 \mathrm{~mm}$ and $100 \mathrm{~mm}$, and maximum annual consecutive 2-day precipitation (RX2) and maximum annual consecutive 3-day (RX3) were representative of the maximum amount of precipitation in 2 and 3 days, respectively.

The trend of total seasonal precipitation was evaluated for spring, summer, fall and winter. Yearly seasons were used for trend analysis because time series can have seasonalities and autocorrelations that affect the power of the Mann-Kendall test (Blain, 2010), so we chose to organize the time series into seasons and calculate the Mann-Kendall index $\left(Z_{M K}\right)$ for each of them. The Mann-Kendall is a non-parametric statistic test, which is based on rejecting or not of the null hypothesis $(\mathrm{H} 0)$, that there is no trend in the data series, adopting a level of significance (eg $\alpha=0.05)$. 
The statistical variable $S$, for a data series of the Mann-Kendall test, is calculated from the sum of signals (sgn) of the differences, in pairs, of all series values (xi) in relation to future values (xj), given by Equations 1 and 2 (Salviano et al., 2016).

$S=\sum_{i=1}^{n-1} \sum_{j=i+1}^{n} \operatorname{sgn}(x j-x i)$

$\operatorname{sgn}(x j-x i)=\left\{\begin{array}{c}+1 ; \text { if } x j>x i \\ 0 ; \text { if } x j=x i \\ -1 ; \text { if } x j<x i\end{array}\right\}$

When $\mathrm{n} \geq 10$, the variable $\mathrm{S}$ can be compared with a normal distribution, where its variance, $\operatorname{Var}\left(\mathrm{S}\right.$ ), can be obtained through Equation 3, where $t_{i}$ represents the number of ties $i$ (for example, a time series with three equal values between them would have one repetition equal to 3 , or $\mathrm{t}_{\mathrm{i}}=1$ and $i=3$ ).

$\operatorname{Var}(S)=\frac{n(n-1)(2 n+5)-\sum_{i=1}^{n} t i(i)(i-1)(2 i+5)}{18}$

The $\mathrm{Z}_{\mathrm{mk}}$ index follows the normal distribution, in which its mean is zero, positive values indicate increasing trend while negative values indicate decreasing trend. According to the $S$ signal, the $\mathrm{Z}_{\mathrm{mk}}$ index of the normal distribution is calculated through the system of equations below (Equation 4).

$Z_{M K}=\frac{S-1}{\sqrt{\operatorname{Var}(S)}} ;$ for $S>0$
$Z_{M K}=0 ;$ for $S=0$
$Z_{M K}=\frac{S+1}{\sqrt{\operatorname{Var}(S)}} ;$ for $S<0$

Since it is a two-tailed test, to reject $\mathrm{H} 0$, the absolute value of $\mathrm{Z}_{\mathrm{mk}}$ must be greater than $\mathrm{Z}_{\alpha / 2}$. For example, for $\alpha=5 \%, \mathrm{Z}_{0.05 / 2}=1.96$, it will be considered that the series has a significant trend at the $5 \%$ level if $\mathrm{Z}_{\mathrm{mk}}>1.96$.

The Rainfall Anomaly Index (RAI) is used for temporal analysis of anomalies in time series, adapted for Brazil by Freitas (1998) (Equations 5 and 6).

$R A I=3\left[\frac{N-\bar{N}}{\bar{M}-\bar{N}}\right]$

$R A I=-3\left[\frac{N-\bar{N}}{\bar{X}-\bar{N}}\right]$

Equation 5 is used for positive anomalies and Equation 6 for negative anomalies, where: $\mathrm{N}=$ current annual precipitation, which is the year that RAI is generated $(\mathrm{mm}) ; \bar{N}=$ annual mean rainfall of time series (mm); $\bar{M}=$ average of the ten largest annual precipitations of time series $(\mathrm{mm}) ; \bar{X}=$ average of the ten lowest annual precipitations of time series (mm); where positive anomalies are above the mean and negative, below the mean. 
In addition, the obtained RAIs (positive or negative) were compared with the years under the influence of El Niño and La Niña phenomena, in order to seek associations with the RAI intensity classes. The information about the occurrence of El Niño-Southern Oscillation (ENSO) was obtained from the website of the National Weather Service Climate Prediction Center (NOAA).

\section{RESULTS AND DISCUSSION}

\subsection{Seasonal Trend}

Before applying the Seasonal Mann-Kendall test, a run test was performed to ensure the randomness of the seasonal series or lack of autocorrelation (Table 1).

Table 1. Results of run test on seasonal data series from weather stations at Lages, São Joaquim and Campos Novos.

\begin{tabular}{lccc}
\hline Season & $\begin{array}{c}\text { Lages } \\
\text { p-value }\end{array}$ & $\begin{array}{c}\text { São Joaquim } \\
\text { p-value }\end{array}$ & $\begin{array}{c}\text { Campos Novos } \\
\text { p-value }\end{array}$ \\
\hline Summer & 0,770 & 0,360 & 0,700 \\
Fall & 1,000 & 0,336 & 0,700 \\
Winter & 0,381 & 0,749 & 0,700 \\
Spring & 0,037 & 0,211 & 0,248 \\
\hline
\end{tabular}

H0: randomness; right-sided test.

The precipitation time series from the city of Lages indicates a significant increase in seasonal precipitation in spring $(\mathrm{p}$-value $=0,001)$ and winter $(\mathrm{p}$-value $=0,011)$, the rainiest and driest seasons, respectively (Fig. 2).

In Lages, the results indicate positive trends of precipitation during the analyzed period, as was reported by another study in this city (Costa et al., 2015). This increase may be related to the increase in air temperature in the southern region of Brazil, which is more expressive in winter compared to summer (Marengo and Camargo, 2008).

The increase in the air temperature intensifies the process of natural convection, increasing the occurrence of convective rains. This would also explain the increasing trend of rainfall during the spring (p-value $=0,008)$ and summer $(p$-value $=0,018)$ in São Joaquim, which are the rainier seasons with a mean of total seasonal rainfall of 481 and $471 \mathrm{~mm}$, respectively (Fig. 3).

The increasing trend in spring is in accord with another study that found a significant increasing trend of rainfall between October and December for the city of Urussanga $(100 \mathrm{~km}$ from São Joaquim) (Back, 2001). The annual variability of the total precipitation oscillates between values above and below the seasonal precipitation mean of the period in all seasons; however, in the last decades a greater positive deviation than mean is observed in the seasons of the year in which there is trend.

There is no trend to seasonal total precipitation in Campos Novos (Fig. 4), which may be explained due to the short time series available in this weather station for the trend test. The absence of the decades of 60 and 70 in the time series influenced the test results. In order to prove this, the withdrawal of these decades was simulated from the time series of Lages and São Joaquim, verifying the influence of this period in the test, which did not present significant trend in this case. 
Summer

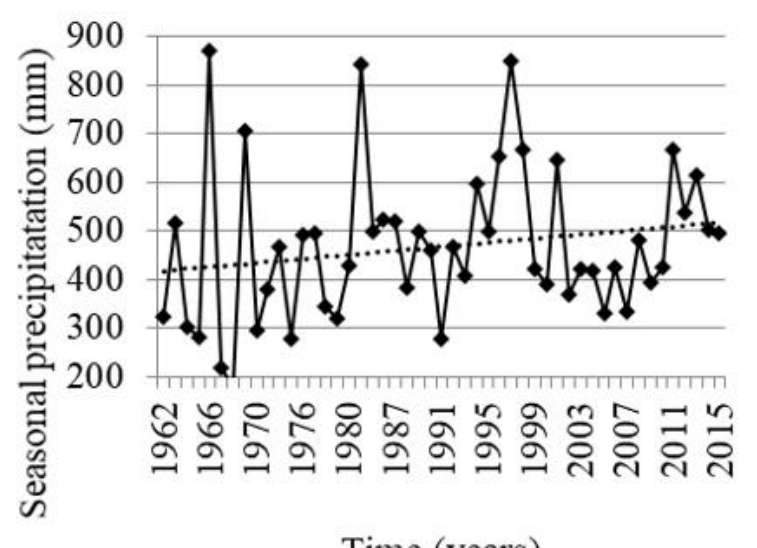

Time (years)

Winter

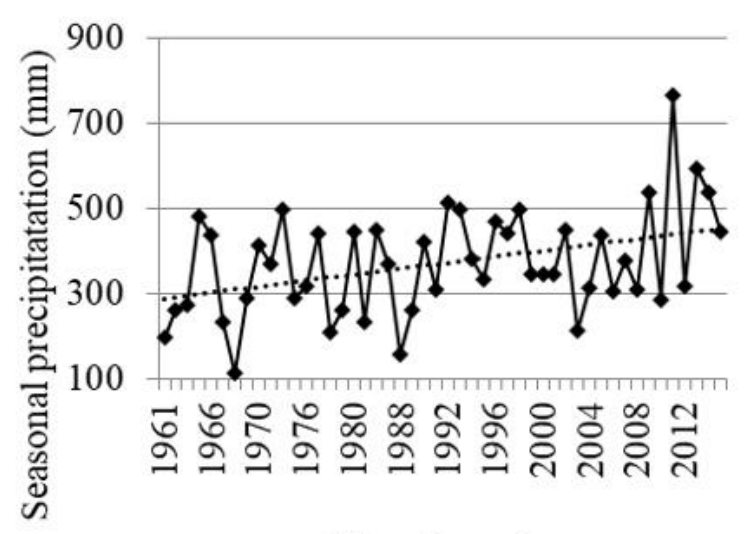

Time (years)
Fall

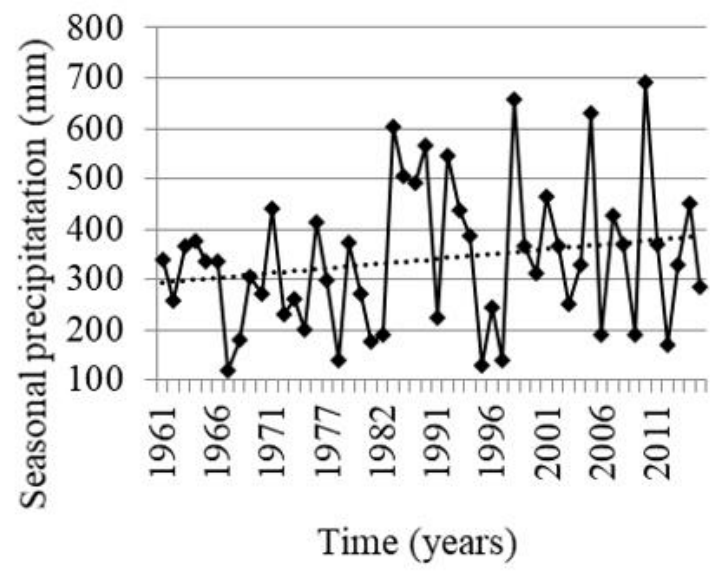

Spring

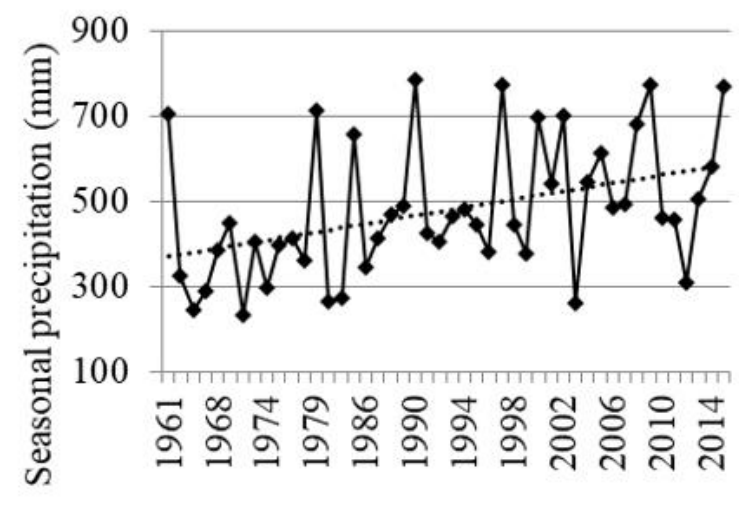

Time (years)

Figure 2. Seasonal precipitation trend for Lages. 


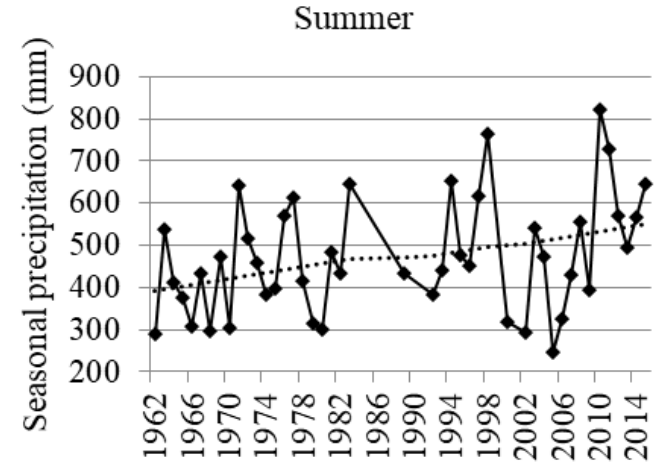

Time (years)

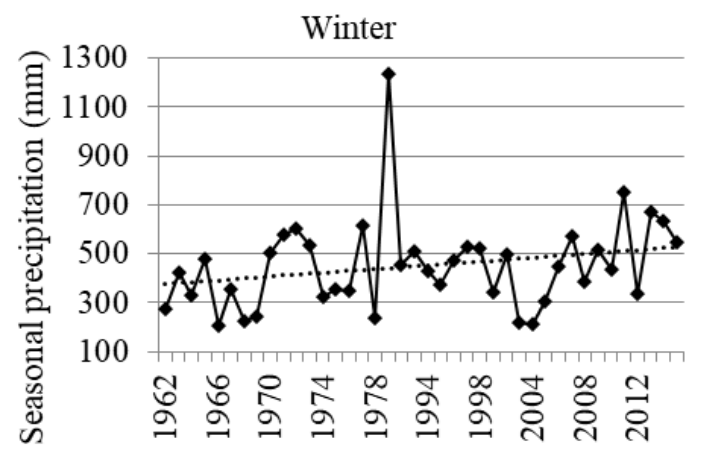

Time (years)
Fall

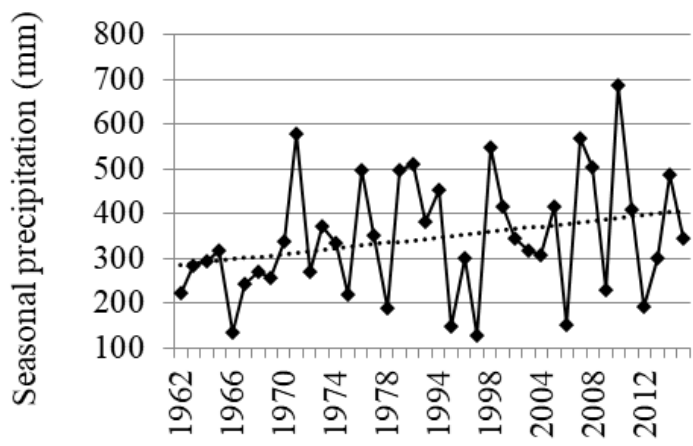

Time (years)

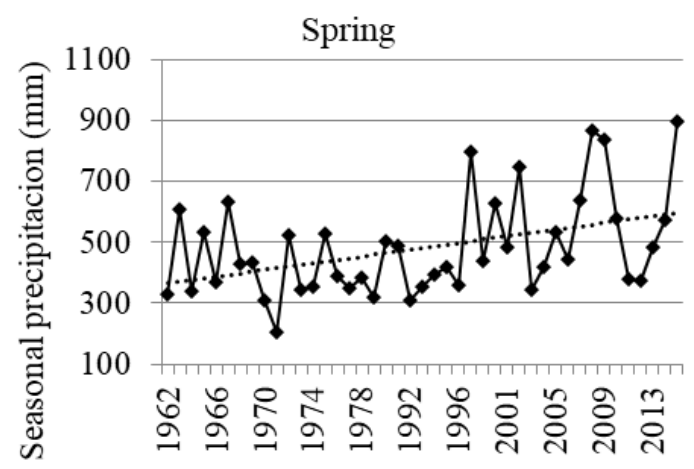

Time (years)

Figure 3. Seasonal precipitation trends for São Joaquim.

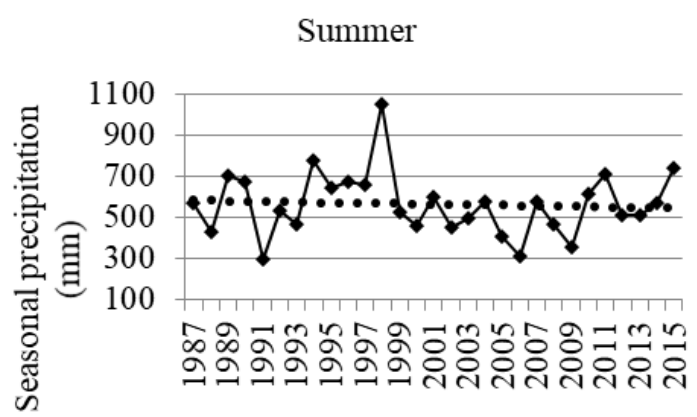

Time (year)

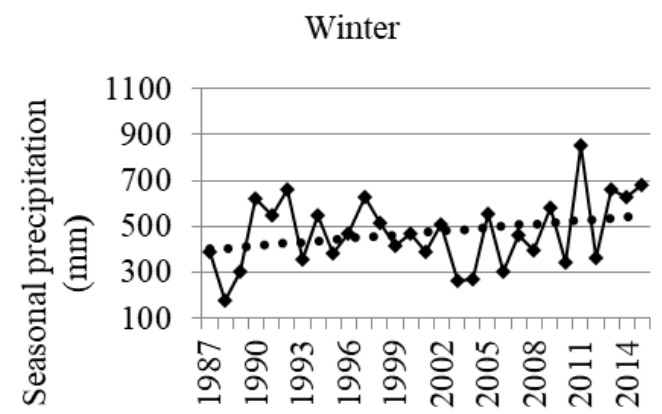

Time (year)

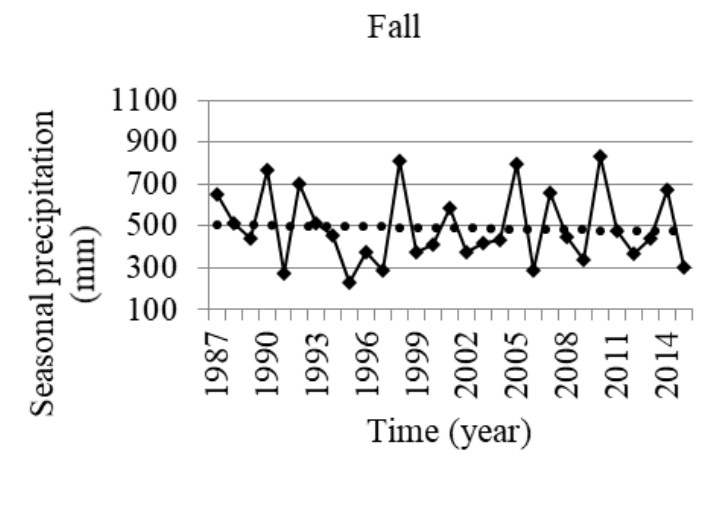

Spring

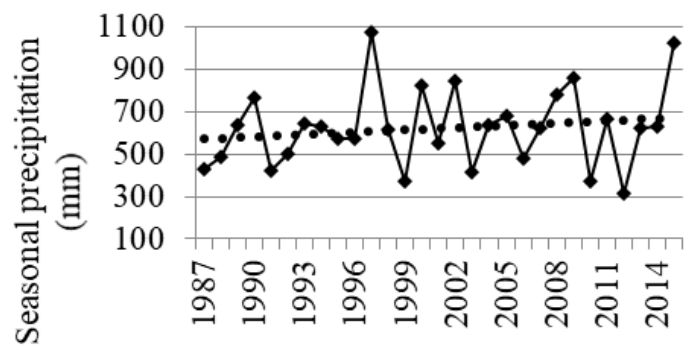

Time (year)

Figure 4. Seasonal precipitation trend for Campos Novos. 


\subsection{Frequency Distribution of RX1, RX2 and RX3}

The frequency distribution showed an increasing trend for the RX1 when evaluating events greater than $50 \mathrm{~mm}$ and $100 \mathrm{~mm}$. In Lages, the highest value of precipitation found was $176.8 \mathrm{~mm}$ in October 2001, $124.2 \mathrm{~mm}$ in July 1983 for São Joaquim, and $159.4 \mathrm{~mm}$ in May 1990 for Campos Novos. This corroborates another study developed in three states of the southern Brazil, where an increase in the maximum daily rainfall was observed in 14 of 18 rainfall gauges (Pinheiro et al., 2013). Despite this, a study conducted in the Rio Grande do Sul State from climate models did not detect trends in RX1 (Melo, 2015), which highlights the importance of these studies at the regional level.

The analyses of RX2 and RX3 showed an increase in frequencies for Lages and São Joaquim, showing that there is an increase in the duration of the rainfalls.

In Lages and São Joaquim, the frequency of days per year in which there are rains of RX2 is in the range of 20 to 50 days and the frequency of days per year that occur RX3 varies from 5 to 35 days.

There is no trend in RX2 and RX3 for Campos Novos, an effect that may be explained by the lesser amount of available data under analysis, since the frequency of days per year in which there are rains of RX2 range from 30 to 50 days, the same that in the other stations. However, the years where the lowest frequencies of RX2 occurs in Lages and São Joaquim are those missing in the time series of Campos Novos.

\subsection{Rainfall Anomaly Index}

The RAI for Campos Novos presented a wide range, from extremely wet years, such as in 1990, 1998 and 2015, to extremely dry years, as in 2006. The RAI values for Lages and São Joaquim also presented this range, though higher frequencies are observed in wet and very wet classes for recent years. These results indicate that, since 2007, only 2012 did not fit into the classes with positive anomalies, which may be related to a significant episode of La Niña phenomenon in this year.

As discussed previously, this behavior may be associated with the higher air temperature values observed for the recent years (Marengo and Camargo, 2008). Through the occurrence of higher air temperatures, warm air, due to its low density and weight, submits itself to the convection process, increasing the occurrence of rainfalls with strong intensity.

Although there is an increase in the occurrence of positive RAI for the recent years in Lages and São Joaquim, this trend is not observed in Campos Novos, which possibly may be related to the shorter length of data available used in the analysis. The shorter temporal range limited the revelation of trends and positive anomalies due to the absence of the decades of 60 and 70 .

To verify if this increasing trend of the positive anomalies is associated to the occurrence of positive sign (El Niño) or negative sign (La Niña) of the ENOS phenomenon, the RAI's obtained for Lages were related to the classification of ENOS in Table 2.

It is noticed that $55 \%$ of the years in which positive anomalies are observed were under El Niño effect. Of the rest, in $41 \%$ of cases there was an effect of La Niña. For the negative anomalies, there was a correspondence of $47 \%$ with La Niña and $61 \%$ with the occurrence of El Niño. An initial evaluation of these values would indicate a low correspondence between the occurrences of positive or negative anomalies with the occurrence of the positive or negative sign for the ENSO phenomenon. However, it is known that the response of the climate variables in the ENSO phenomenon are not instantaneous, which means that the occurrence of a configured El Niño event in a certain year may only affect the climate of the next year (GRIMM et al., 2000). 
Table 2. Years with the occurrence of El Niño and La Niña and signs of RAI for Lages.

\begin{tabular}{llcclc}
\hline Year & NOAA & RAI & Year & NOAA & RAI \\
\hline 1961 & Neutral & - & 1995 & El Niño/La Niña & - \\
1962 & Neutral & - & 1996 & La Niña & + \\
1967 & La Niña & - & 1997 & El Niño & + \\
1968 & El Niño/La Niña & - & 1998 & El Niño/La Niña & + \\
1969 & El Niño & - & 1999 & La Niña & - \\
1971 & La Niña & - & 2000 & La Niña & + \\
1972 & El Niño/La Niña & - & 2001 & La Niña & + \\
1974 & La Niña & - & 2002 & El Niño & + \\
1976 & El Niño/La Niña & - & 2003 & El Niño & - \\
1977 & El Niño & - & 2004 & El Niño & - \\
1978 & El Niño & - & 2005 & El Niño & + \\
1979 & El Niño & - & 2006 & El Niño & - \\
1981 & Neutral & - & 2007 & El Niño/La Niña & + \\
1982 & El Niño & + & 2008 & La Niña & + \\
1987 & El Niño & + & 2009 & El Niño & + \\
1988 & El Niño/La Niña & - & 2010 & El Niño/La Niña & + \\
1989 & La Niña & + & 2011 & La Niña & + \\
1990 & Neutral & + & 2012 & La Niña & - \\
1991 & El Niño & - & 2013 & Neutral & + \\
1992 & El Niño & + & 2014 & Neutral & + \\
1993 & Neutral & + & 2015 & El Niño & + \\
1994 & El Niño & + & & & + \\
\hline
\end{tabular}

RAI: + (positive), - (negative).

The occurrence of El Niño influences the occurrence of positive rainfall anomalies in southern Brazil (Raimundo et al., 2014). In order to find these relationships, a graph was created relating the occurrence of the positive or negative signs for the ENSO phenomenon with the RAI obtained for the three cities under study (Fig. 5). 


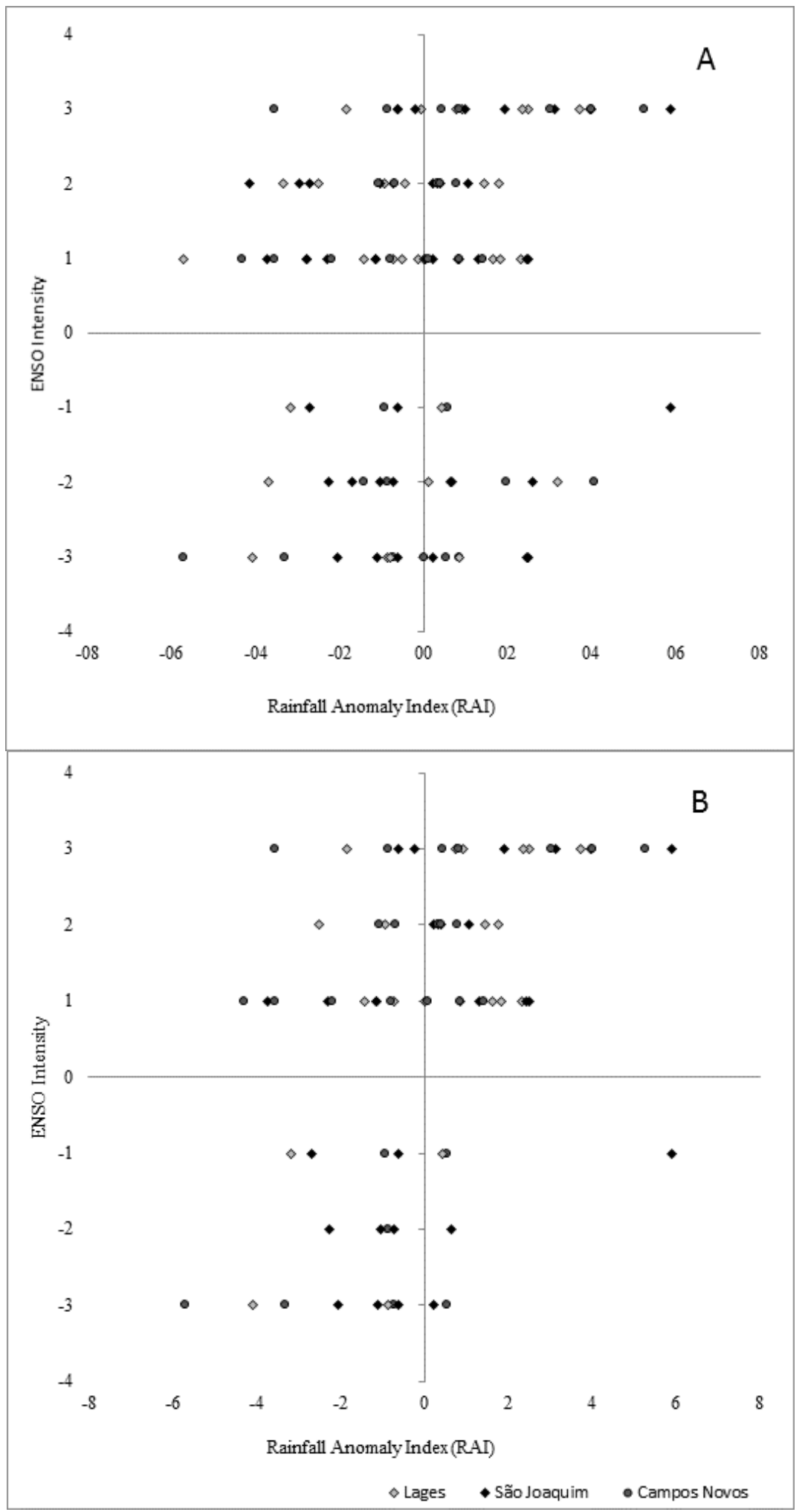

Figure 5. Correlation between RAI and occurrence of ENSO phenomenon at different intensities. In the $\mathrm{Y}$ axis, the figures indicate the intensity of the ENSO phenomenon: 1 = Weak intensity; $2=$ Moderate intensity; $3=$ Strong intensity; Positive values indicate the occurrence of El Niño and negatives indicate the occurrence of $\mathrm{La}$ Niña. (A) Using all the years of the study; (B) With the withdrawal of the decades of 1960 and 1970 for El Niño and the decade of 2000 for La Niña. 
It is verified that in case of an El Niño with strong intensity, the majority of the RAI values are positive, while in the cases of La Niña with strong intensity the RAI values are negative (Fig. 5-A). In other words, the stronger the intensity of El Niño, the greater the occurrence of positive anomalies, and the stronger the intensity of La Niña, the greater the occurrence of negative anomalies. Consequently, it can be affirmed that more important than the occurrence of the phenomenon is the intensity.

In an individual analysis of each event, it is observed that the correspondence between the occurrence of El Niño and positive anomalies has been more intense in recent years, especially since the decade of the 1980s. This can be verified when the years before 1980 are withdrawn from the analysis, as seen in Figure 5-B. It is then confirmed that with the withdrawal of the decades of the 1960s and 1970s, there is a major predominance of occurrence of positive anomalies associated with a moderate and strong El Niño event.

On the other hand, it was observed that the influence of La Niña in the periods of negative anomaly has been reduced since the beginning of the 21 st century. The Figure 5-B shows that the withdrawal of the years older than 2000 significantly increases the relationship between La Niña and the occurrence of negative anomalies.

The results indicate a decreasing in the effect of La Niña, which may be associated with the increase in temperature observed in the region for the recent years (Marengo and Camargo, 2008) or the intensity and duration of these events. However, this results must be evaluated for other regions to confirm if this tendency corresponds to the entire region of southern Brazil or just the highlands region.

The results of increasing trends in Lages and São Joaquim differ from a study of trends analysis of precipitation and temperature data in Brazil, which showed no significant trends in over $70 \%$ of the Brazilian territory in all months in the precipitation (Salviano et al., 2016). The difference found may due to the stations selected in Santa Catarina for that study, what supports the idea that more regional studies must be developed to understand the trends in precipitation locally.

\section{CONCLUSIONS}

There is an increasing trend of seasonal precipitation in the spring and winter for Lages, while for São Joaquim, increasing trends are found for the spring and summer seasons. There is no statistically significant trend in Campos Novos, which is possibly justified due the short series of available data. It can be observed that the rainfall frequency distribution is aligned with the seasonal trend analysis, with an increase in the frequency of maximum rainfall, as well as for the RX2 and RX3 rainfalls. Therefore, there is an increase in the number of extreme episodes and the number of days with rainfall.

The RAI values for Lages and São Joaquim confirmed that the higher frequencies in the wet and very wet classes have increased in recent years. The correlation between RAI and the occurrence of the ENSO phenomenon indicates that the greater the intensity of the ENOS phenomenon, the greater the occurrence of anomalies. In addition, the influence of the La Niña in the periods of negative anomaly has been reduced since the beginning of the 21 st century. Despite this, it is recommended that this relationship to be studied in other regions to confirm the statement.

\section{ACKNOWLEDGEMENTS}

The autors thanks the Uniedu (n.19/SED/2015) for the concession of funding to the second author during the development of this study. 


\section{REFERENCES}

BACK, A. J. Aplicação de análise estatística para identificação de tendências climáticas. Pesquisa Agropecuária Brasileira, v. 36, n. 5, p. 717-726, 2001.

BLAIN, G. C. Tendências e variações climáticas em séries anuais de precipitação pluvial do Estado de São Paulo. Bragantia, v. 69, n. 3, p. 765-770, 2010.

COSTA, V. J.; FERREIRA, M.; CORDEIRO, M. T. A. Análise de séries temporais climáticas. Revista de Ciências Agroveterinárias, v. 14, n. 2, p. 169-177, 2015.

FREITAS, M. A. S. Um sistema de suporte à decisão para o monitoramento de secas meteorológicas em regiões semi-áridas. Revista Tecnologia, v. 19, n. 1, p. 19-30, 1998.

GRIMM, A. M.; BARROS, V. R.; DOYLE, M. E. Variability in Southern South America associated with El Niño and La Niña events. Journal of Climate, v. 13, 2000.

GROPPO, J. D.; MILDE, L. C; MORAES, J. M.; GUANDIQUE, E. M.; MARTINELLI, L. A. Análise da vazão e da precipitação na bacia do Rio Piracicaba: Detecção de sinais devido a intervenções antrópicas. Revista de Ciência e Tecnologia, v. 9, n. 18, 2001.

HIRSCH, R. M.; SLACK, J. R.; SMITH, R. A. Techniques for trend assessment for monthly water quality data. Water Resources Research, v. 18, p. 107-121, 1982.

IPCC. Summary for policymakers. In: PARRY, M. L. et al. (Ed.). Climate change 2007: impacts, adaptation and vulnerability; contribution of the Working Group II to the Fourth Assessment Report of the Intergovernmental Panel on Climate Change. Cambridge (UK): Cambridge University Press, 2007. p. 7-22.

LIEBMANN, B.; VERA, C. S.; CARVALHO, L. M. V.; CAMILLONI, I. A.; HOERLING, M. P.; ALLURED, D.; BARROS, V. R; BÁEZ, J.; BIDEGAIN, M. An observed trend in Central South American precipitation. Journal of Climate, v. 17, n. 22, p. 4357-4367, 2004.

LIMA, J. R. A.; NEVES, D. J. D.; ARAÚJO, L. E.; AZEVEDO, P. V. Identificação de tendências climáticas no Estado da Bahia. Revista de Geografia, v. 28, n. 3, p. 172-187, 2011.

MARENGO, J. A.; CAMARGO, C. C. Surface air temperature trends in Southern Brazil for 1960 - 2002. International Journal of Climatology, v. 28, p. 893-904, 2008.

MELO, T. M. Simulação estocástica dos impactos das mudanças climáticas sobre as demandas de água para irrigação na região noroeste do Rio Grande do Sul. 2015. Tese (Doutorado em Recursos Hídricos e Saneamento Ambiental) - Universidade Federal do Rio Grande do Sul. Porto Alegre, julho de 2015.

MINUZZI, R. B.; CARAMORI, P. H. Variabilidade climática sazonal e anual da chuva e veranicos no Estado do Paraná. Revista Ceres (Impresso), v. 58, n. 5, p. 593-602, 2011.

NORONHA, G. C.; DA HORA, M. A. G. M.; SILVA, L. P. Análise do índice de anomalia de chuva para a microbacia de Santa Maria/Cambiocó, RJ. Revista Brasileira de Meteorologia, v. 31, n. 1, p. 74-81, 2016. 
PINHEIRO, A.; GRACIANO, R.; SEVERO, D. Tendências das séries temporais de precipitação da região sul do Brasil. Revista Brasileira de Meteorologia, v. 28, n. 3, p. 281-290, 2013.

RAIMUNDO, C. C.; SANSigOlO, C. A.; MOLION, L. C. B. Tendências das classes de precipitação na região metropolitana de São Paulo. Revista Brasileira de Meteorologia, v. 29, n. 3, p. $397-408,2014$.

SALVIANO, M. F.; GROPPO, J. D.; PELLEGRINO, G. Q. Análise de tendências em dados de precipitação. Revista Brasileira de Meteorologia, v. 31, n. 1, p. 64 - 73, 2016.

SANCHES, F. O.; VERDUM, R.; FISCH, G. Estudo de tendência de chuvas de longo prazo. Revista Ambiente \& Água, v. 8, n. 3, p. 214-228, 2013.

ULIANA, E. M.; SILVA, D. D.; ULIANA, E. M.; RODRIGUES, B. S.; CORRÊDO, L. P. Análise de tendência em séries históricas de vazão precipitação: uso de teste estatístico não paramétrico. Revista Ambiente \& Água, v. 10, n. 1, 2015.

YEVJEVICH, V. Probability and statistics in hydrology. Fort Collins: Water Resources Publication, 1972. $276 \mathrm{p}$. 